ROCZNIKI NAUK SPOŁECZNYCH

Tom 12(48), numer $4-2020$

DOI: https://doi.org/10.18290/rns20484-4

MONIKA MARIA BRZEZIŃSKA

\title{
KONFLIKT NA UKRAINIE \\ W NIEMIECKIM DYSKURSIE PARLAMENTARNYM
}

\section{WPROWADZENIE}

Niniejsza analiza dotycząca priorytetów polityki zagranicznej Niemiec wobec Ukrainy (i pośrednio wobec Rosji) oparta została na 58 protokołach debat parlamentarnych ${ }^{1}$ przeprowadzanych na forum Bundestagu (BT) w okresie od 30 marca 2012 r. do 25 maja 2014 r. Celem artykułu było pokazanie zagadnień poruszanych przez niemieckich deputowanych, ale także stopnia ich zaangażowania oraz proponowanych ewentualnych narzędzi mających za zadanie rozwiązanie konfliktu na Ukrainie.

Sam artykuł podzielony został - ze względu na dynamikę wydarzeń - na trzy części: „Przed Majdanem” (30 III 2012 - 21 XI 2013), „Majdan” (22 XI 2013 - 26 II 2014) oraz „Po Majdanie” (27 II 2014 do 25 V 2014). Należy jednak mieć na uwadze, iż eskalacja tarć na Ukrainie była bardzo dynamiczna i sam badany okres dyskursu politycznego stanowi jedynie niewielki wycinek badanej rzeczywistości politycznej.

W związku z powyższym, przyjmując za podstawę badań metodę analizy narracji politycznej, podjęto się próby odpowiedzi na następujące pytania: 1. Jakie kwestie były najczęściej poruszane na forum Bundestagu w związku z sytuacją na Ukrainie? 2. Jak zmieniał się, jeśli w ogóle, dyskurs prowadzony przez niemieckich deputowanych na przestrzeni dwóch poddanych analizie lat

Dr MoniKa Maria BRZEZiŃSKA - Katedra Stosunków Międzynarodowych i Studiów Europejskich w Instytucie Nauk o Polityce i Administracji, Uniwersytet Kardynała Stefana Wyszyńskiego w Warszawie; adres do korespondencji: ul. Wóycickiego 1/3 bud. 23, 01-938 Warszawa; e-mail: m.brzezinska@uksw.edu.pl; ORCID: https://orcid.org/0000-0001-9278-9931.

${ }^{1}$ Liczba protokołów z posiedzeń parlamentarnych zdeterminowana została częstotliwością poruszanych przez niemieckich deputowanych kwestii związanych z sytuacją polityczną na Ukrainie w badanym przedziale czasowym. Wszystkie analizowane protokoły są dostępne na: http://www.bundestag.de/protokolle. 
w kontekście poruszanych przez nich kwestii? 3. Co de facto kryło się za niemiecką narracją parlamentarną i jakimi motywami kierowała się A. Merkel w swojej polityce wschodniej wobec Ukrainy?

\section{PRZED MAJDANEM (30 III 2012 - 21 XI 2013)}

Tak zwany okres przed Majdanem w narracji niemieckich deputowanych do Bundestagu zapoczątkowały w głównej mierze zbliżające się mistrzostwa w piłce nożnej (Euro 2012), które miały odbyć się m.in. na Ukrainie. Wydarzenie to stało się dla parlamentarzystów przyczynkiem do dalszych, pogłębionych rozważań na temat potrzeby demokratyzacji Ukrainy i walki o poszanowanie praw człowieka, w tym również przestrzegania nagminnie łamanych $\mathrm{w}$ tym kraju reguł państwa prawa ${ }^{2}$. Politycy proponowali bojkot lub przeniesienie rozgrywek gdzie indziej, co z kolei wywiązało szeroką dysputę na temat zasadności instrumentalizacji sportu i wykorzystania go do celów politycznych. Nadto debata pokazała również skalę oddziaływania inicjatyw o charakterze niepolitycznym na sferę stosunków i układ sił międzynarodowych.

O ile bowiem część niemieckich polityków (głównie z CDU, Unia Chrześcijańsko-Demokratyczna Niemiec) popierała zarówno ideę organizacji samych mistrzostw, jak i konieczność osobistej wizyty Angeli Merkel w Kijowie ${ }^{3}$, o tyle już inni (FDP - Wolna Partia Demokratyczna ${ }^{4}$ i SPD - Socjaldemokratyczna Partia Niemiec ${ }^{5}$ ) zdecydowanie uważali, że przyjazd kanclerz mógłby być odebrany przez ówczesną władzę ukraińską jako wyraz akceptacji prowadzonej przez W. Janukowycza polityki. A. Merkel stanęła zatem nie tylko przed dylematem podziału własnej, wewnętrznej sceny politycznej, ale także zdawała sobie sprawę, iż decyzja jej będzie odczytana jako gest o wydźwięku międzynarodowym, bacznie obserwowanym zarówno przez W. Putina, jak i przez innych przywódców świata polityki. Do ostatniej zatem chwili, o czym informował rzecznik rządu S. Stoiber, nie wypowiadała się na temat swojej podróży ${ }^{6}$,

\footnotetext{
${ }^{2}$ Por. więcej na: Deutscher Bundestag, Keine Eishokey-Weltmeisterschaft 2014 in Bielarus, Drucksache 17/9557, 9. Mai 2012, http://dip21.bundestag.de/dip21/btd/17/095/1709557.pdf (dostęp: 10.09.2014).

${ }^{3}$ Por. Plenarprotokoll 17/187, Deutscher Bundestag, Stenografischer Bericht, 187. Sitzung, Berlin den 28. Juni 2012, s. 273.

${ }^{4}$ Por. tamże, s. 275.

${ }^{5}$ Por. tamże, s. 274.

${ }^{6}$ Por. „Wprost”, Merkel nie zaplanowata wyjazdu na Euro 2012, wprost.pl 4.06.2012, https://www.wprost.pl/326323/merkel-nie-zaplanowala-wyjazdu-na-euro-2012.html (dostęp: 16.08.2020).
} 
uzależniając obecność na mistrzostwach od wypuszczenia na wolność byłej premier i opozycjonistki J. Tymoszenko. Ostatecznie kanclerz spotkała się z niemieckimi piłkarzami nie w Kijowie, lecz w Warszawie, a jej obecność umknęła $\mathrm{w}$ zasadzie opinii publicznej i nie została szerzej nagłośniona (,wpadła jak po ogień”, „była, ale jakby jej nie było"7 ).

Co interesujące polityczny wątek łamania praw człowieka i mających tam miejsce aktów przemocy bardzo szybko przekształcił się w dyskusję parlamentarną na temat dyskryminacji na tle seksualnym. Na równi z kwestiami walki o demokrację i wolność zwracano bowiem uwagę na pojawiające się uchybienia i szykany, w tym na odwołanej w Kijowie paradzie Guy Pride ${ }^{8}$. Część niemieckich deputowanych (głównie z SPD $^{9}$ ) uznała to za stygmatyzowanie i dyskryminowanie grup homoseksualnych na Ukrainie oraz zwróciła uwagę na potrzebę edukacji w zakresie gejowskiej tożsamości (schwule Identität) i bezpiecznego seksu (Safer Sex $)^{10}$.

Różnorodność podejmowanych kwestii, a także ich wielowątkowość wskazywać by zatem mogły, iż Niemcom zależało nie tylko na ochronie praw podstawowych związanych z funkcjonowaniem systemu politycznego, ale swoją rolę postrzegali znacznie szerzej: jako promotora „miękkiej dyplomacji”, w tym obrońcę nowych ideologii (LGBTQ+). Uważali się zatem za swoisty „pas transmisyjny” zachodniej kultury i jej progresywnych wartości w tej części Europy.

Niemniej nie zabrakło również i odniesień do interesów narodowych Niemiec. Zwracano mianowicie uwagę, iż to Republika Federalna Niemiec (RFN) wraz z Francją winny stać się europejskim centrum decyzyjnym ${ }^{11}$ i adwokatem wschodnioeuropejskich narodów ${ }^{12}$. Narracja ta stawiała zatem Polskę poza przyszłym układem sił w tym rejonie i usuwała ją ze wspomnianego obszaru decyzyjnego, rezerwując przestrzeń wpływów dla A. Merkel oraz dla F. Hollande'a, a także dla stojącej za nimi UE. Nadto dla Niemców, jak wykazała prowadzona dyskusja, zinstytucjonalizowaną formą, priorytetem i „kanałem”

\footnotetext{
${ }^{7}$ Dziennik.pl, Byta, a jakby jej nie było. Cicha wizyta Merkel u niemieckich pitkarzy, dziennik.pl 7.06.2012, https://www.dziennik.pl/euro2012dziennikpl/galeria/393400,kanclerzniemiec-angela-merkel-odwiedzila-w-gdansku-niemieckich-pilkarzy-przed-pilkarskimimistrzostwami-euro-2012.html (dostęp: 16.08.2020).

${ }^{8}$ Por. Plenarprotokoll 17/181, Deutscher Bundestag, Stenografischer Bericht, 181. Sitzung, Berlin den 24. Mai 2012, s. 173.

${ }^{9}$ Por. tamże, s. 175-176.

${ }^{10}$ Por. tamże, s. 234.

${ }^{11}$ Por. Plenarprotokoll 17/179, Deutscher Bundestag, Stenografischer Bericht, 179. Sitzung, Berlin den 11. Mai 2012, s. 6.

${ }^{12}$ Por. Plenarprotokoll 17/194, Deutscher Bundestag, Stenografischer Bericht, 194. Sitzung, Berlin den 26. September 2012, s. 54.
} 
relacji z Ukrainą miało stać się Partnerstwo Wschodnie ${ }^{13}$. Kanclerz rozumiała je jednak jako instrument gospodarczy, ewentualnie element soft power, ale nie jako proces polityczny ${ }^{14}$. Obawiała się bowiem reakcji Rosji, z którą Niemcy, zwłaszcza za rządów kanclerza G. Schrödera, łączyły dobre relacje i która to obszar Ukrainy uważała za swoją historyczną i naturalną strefę wpływów.

A. Merkel pozostawała zatem zdystansowana geopolitycznie, koncentrując się na aspektach gospodarczych ${ }^{15} \mathrm{i}$ transferze niekoniecznie politycznych wartości. Kwestie reformy ustrojowej Ukrainy, choć poruszane, pozostawały drugoplanowe, a sama kanclerz na przestrzeni badanych miesięcy zabrała głos w tej sprawie jedynie dwukrotnie. Po raz pierwszy odnosząc się do palących i niezbędnych do przezwyciężenia problemów, oferując jednocześnie Ukrainie w ramach europejskiej solidarności pomoc finansową na dalszy jej rozwój ${ }^{16}$. Po raz drugi zaś wskazując na istotę interesów Niemiec i UE w zakresie reform, praw człowieka i prosperity gospodarczego w nawiązaniu do europejskich wartości tj. demokracji czy wolności obywatelskich. A. Merkel obiecała nadto wsparcie finansowe dla Ukrainy ze środków europejskiej polityki sąsiedztwa i paktu o wzajemnej pomocy (w sumie ponad pół miliarda euro), zobowiązując się do wywarcia wpływu na samą UE, w zakresie gospodarczym odnośnie do „możliwości zastępczych" dostaw energii i eksportu towarów ${ }^{17}$. Kwestia ta pozostawała dla Niemców o tyle ważna, iż jednym z priorytetów ich rządu w owym czasie było m.in. bezpieczeństwo energetyczne i dążenie do dywersyfikacji jej źródeł. Poszukiwali zatem partnerów, którzy by ich w tej koncepcji poparli.

Wypowiedź kanclerz wymaga szczególnej uwagi ze względu na poruszony przez nią wątek interesów gospodarczych Niemiec, w tym ekonomicznego znaczenia Ukrainy jako strategicznego centrum handlu i surowców ${ }^{18}$. Trzeba bowiem mieć na uwadze, iż od momentu nawiązania współpracy dyplomatyczno-gospodarczej RFN

\footnotetext{
${ }^{13}$ Por. więcej na: Deutscher Bundestag, Umfassende Visaliberalisierung für Menschen in Russland und Osteuropa, Drucksache 17/191, 28. März 2012, http://dip21.bundestag.de/dip21/btd/17/091/17091 91.pdf (dostęp: 12.09.2014).

${ }^{14}$ Por. J. GutowsKa, Niemcy wobec Partnerstwa Wschodniego, „Ośrodek Studiów Wschodnich”, nr 37, 17.06.2010, https://www.osw.waw.pl/sites/default/files/komentarze_37_0.pdf (dostęp: 20.08.2020).

${ }^{15}$ Por. K. MAlinOwsKi, Polityka Niemiec wobec Europy Wschodniej: Russia first?, „Przegląd Polityczny" 2015, nr 4, s. 19-20. DOI: https://doi.org/10.14746/pp.2015.20.4.2.

${ }^{16}$ Por. Regierungserklärung, Plenarprotokoll 17/178, Deutscher Bundestag, Stenografischer Bericht, 178. Sitzung, Berlin den 10. Mai 2012, s. 19.

${ }^{17}$ Por. Regierungserklärung, Plenarprotokoll 18/002, Deutscher Bundestag, Stenografischer Bericht, 2. Sitzung, Berlin den 18. November 2013, s. 5-6.

${ }^{18}$ Por. Plenarprotokoll 17/184, Deutscher Bundestag, Stenografischer Bericht, 184. Sitzung, Berlin den 14. Juni 2012, s. 204.
} 
z Ukrainą (17 I 1992 ${ }^{19}$ ), znacząco rozwinął się eksport niemieckich towarów do tego kraju, a jego szczytowy moment przypadł właśnie na lata 2010-2012, osiągając w 2012 r. najwyższy poziom 68,53 miliardów dolarów ${ }^{20}$. Nowy rynek zbytu znalazły tam głównie produkty chemiczne (21,5\%), maszyny $(21 \%)$ oraz samochody i pojazdy silnikowe $(14,3 \%)^{21}$. Należy pamiętać, iż obszar Europy Środkowo-Wschodniej stał się dla Niemiec niezmiernie atrakcyjny również ze względu na tanią siłę roboczą oraz bliskość geograficzną ${ }^{22}$.

O skali zainteresowania RFN Ukrainą jako atrakcyjnym rynkiem zbytu i miejscem taniej produkcji świadczyć może chociażby wątek dyskusji dotyczący nieformalnej polityki Niemiec wobec tego kraju. Analiza wykazała bowiem, iż rząd federalny przeznaczał $5 \mathrm{mln}$ euro rocznie na cele związane $\mathrm{z}$ finansowaniem ochrony zwierząt, przy jednoczesnym wsparciu nielegalnych fabryk kur niosek na tym terenie, dotując je kwotą $26 \mathrm{mln}$ euro rocznie ${ }^{23}$. Co więcej, prowadzenie interesów w szarej strefie oraz uprawianie polityki przez pryzmat podwójnej moralności, łamiącej - jak to określili sami deputowani - prawo UE i RFN ${ }^{24}$ powiązane było z kolejnymi nielegalnymi interesami (np. pochodzącej z Cypru spółki Avangardco produkującej klatki dla kur), naruszającymi przyjęte standardy i skutkującymi zanieczyszczaniem powietrza i wody na Ukrainie $^{25}$. Niemcy zatem starali się nie tylko pozyskać kolejny rynek, ale i omijać unijne normy, obniżając koszty produkcji, nie ponosząc odpowiedzialności ani za jej skutki uboczne, ani za związane z nimi uchybienia. Oddając pole aktywności politycznej Rosji, zdecydowali się na inwestycje finansowe na Ukrainie, traktując ją jako kolejny obszar własnych wpływów gospodarczych.

\footnotetext{
${ }^{19}$ Por. Deutsche Botschaft, 25 Jahre diplomatische Beziehungen zwischen Deutschland und der Ukraine, erschienen in „Dserkalo tyshnja” am 17.01.2017 Kiew, https://kiew.diplo.de/uade/themen/willkommen/artikel-25-jahre-st-kl/1283092 (dostęp: 13.08.2020).

${ }^{20}$ Por. M. URMENSBACH, Export von Gütern aus der Ukraine bis 2019, Statista 28.04.2020, https://de.statista.com/statistik/daten/studie/314545/umfrage/export-von-guetern-aus-der-ukraine/ (dostęp: 15.08.2020).

21 Por. A. GRIESS, Was Deutschland in die Ukraine liefert, Statista 14.05.2014, https://de.statista.com/infografik/2245/anteil-der-gesamtausfuhr-deutscher-ausfuhrgueter-nach-sitc/ (dostęp: 15.08.2020).

${ }^{22}$ Por. Ł. ANTAS, Relacje gospodarcze Niemiec z krajami Europy Środkowo-Wschodniej, w: Relacje gospodarcze Niemiec z krajami Europy Środkowo-Wschodniej, red. K. Kazimierska, Warszawa: Ośrodek Studiów Wschodnich 2008, s. 4.

${ }^{23}$ Por. Plenarprotokoll 17/192, Deutscher Bundestag, Stenografischer Bericht, 192. Sitzung, Berlin den 13. September 2012, s. 72.

${ }^{24}$ Por. tamże, s. 78.

${ }^{25}$ Por. Plenarprotokoll 17/231, Deutscher Bundestag, Stenografischer Bericht, 231. Sitzung, Berlin den 21. März 2013, s. 113-114.
} 


\section{MAJDAN (21 XI 2013 - 26 II 2014)}

Wstrzymanie przez rząd ukraiński w dniu 21 XI 2013 r. podpisania umowy stowarzyszeniowej o wolnym handlu z Unią Europejską zapoczątkowały w Kijowie w nocy z 21 na 22 listopada protesty tysięcy ludzi, niezgadzających się $\mathrm{z}$ decyzją władz. Powstałe $\mathrm{w}$ ten sposób miasteczko, gromadzące rzesze opozycjonistów, dało początek okresowi tzw. Euromajdanu. Wydarzenie to znalazło swoje odbicie również w aktywności niemieckiego Bundestagu. Krótki czas trzech miesięcy zaowocował 11 debatami parlamentarnymi, podczas których dyskutowano z różnym nasileniem na temat sytuacji na Ukrainie. Najczęściej pojawiającym się wówczas wątkiem pozostawała kwestia rozwoju państwa i jego stabilizacji politycznej w kontekście przyszłości Partnerstwa Wschodniego oraz obaw co do perspektywy demokratyzacji kraju ${ }^{26}$.

Kwestie związane z Ukrainą, a w zasadzie dwutorowość prowadzonej przez nią polityki, znalazły się również w centrum zainteresowania samej A. Merkel. W jednym ze swoich oświadczeń rządowych kanclerz skrytykowała brak konsekwencji władz ukraińskich wobec Rosji. Wspomniała o podpisaniu przez rząd w Kijowie kolejnej umowy z Moskwą, podkreślając, iż w obliczu konfliktu między obu państwami, niezbędne wydaje się odejście od polityki „albo-albo" i skoncentrowanie się na budowaniu mocnej, obywatelskiej, sprawiedliwej oraz konkurencyjnej Europy ${ }^{27}$. Należałoby zatem - w mniemaniu kanclerz - zakończyć praktykowaną przez stronę ukraińską strategią: „być może”, „tak, ale...” czy ,prawdopodobnie" ${ }^{28}$.

Deputowani zwrócili uwagę, iż w przeciwieństwie do niestabilnej i niezdecydowanej polityki W. Janukowycza wobec W. Putina rosyjska taktyka wywierania wpływu politycznego i gospodarczego pozostawała niezmienna, a jej celem było podporządkowanie swojej byłej republiki jako własnej strefy wpływów. Mimo to - zdaniem niemieckich parlamentarzystów - w europejskiej przestrzeni nie powinno być miejsca na hegemonię i na ekonomiczną presję Rosji $^{29}$. Jako środek zaradczy należałoby wzmocnić dialog z Moskwą ${ }^{30}$ oraz

\footnotetext{
${ }^{26}$ Por. Plenarprotokoll 18/003, Deutscher Bundestag, Stenografischer Bericht, 3. Sitzung, Berlin den 28. November 2013, s. 72-73.

${ }^{27}$ Por. Plenarprotokoll 18/017, Deutscher Bundestag, Stenografischer Bericht, 17. Sitzung, Berlin den 20. Februar 2014, s. 13.

${ }^{28}$ Por. Plenarprotokoll 18/005, Deutscher Bundestag, Stenografischer Bericht, 5. Sitzung, Berlin den 18. Dezember 2013, s. 12.

${ }^{29}$ Por. Plenarprotokoll 18/010, Deutscher Bundestag, Stenografischer Bericht, 10. Sitzung, Berlin den 29. Januar 2014, s. 46.

${ }^{30}$ Por. Plenarprotokoll 18/005, Deutscher Bundestag, Stenografischer Bericht, 5. Sitzung, Berlin den 18. Dezember 2013, s. 12.
} 
stworzyć Ukrainie miejsce w środku Europy: w UE i w kooperacji z Rosją właśnie $^{31}$. Konieczne zatem jest wyciągnięcie ręki w kierunku W. Putina ${ }^{32}$, a zapoczątkowany $\mathrm{w}$ ten sposób dialog powinien mieć charakter bilateralny, uwzględniający powiązania historyczne oraz interesy zarówno Kijowa, jak i Moskwy ${ }^{33}$.

Niemcy zatem nie chcieli stawiać Ukrainy przed wyborem „Rosja albo UE”, ale wychodzili z założenia, iż o wiele ważniejsze jest budowanie pomostu ku Moskwie niż bastionu przeciwko niej ${ }^{34}$. Jednocześnie też zwracali uwagę, iż nie można przymykać oczu na dążenia rosyjskiego prezydenta ${ }^{35}$, który stawiał sobie za cel odtworzenie sowieckiego imperium przy jednoczesnym naruszeniu suwerenności i politycznych wyborów obywateli innych państw ${ }^{36}$. Ukraina winna zatem prowadzić bardziej zdecydowaną politykę oraz sama określić swoją dalszą drogę np. poprzez podpisanie umowy stowarzyszeniowej, co byłoby dla Kijowa wsparciem i szansą o wymiarze europejskim ${ }^{37}$. Ważne bowiem jest, by kraj o demokratycznych aspiracjach, chcący należeć do UE, był gotowy podzielać europejskie standardy i wartości, takie jak: pokój, wolność i państwo prawa ${ }^{38}$.

Co interesujące, niemieccy politycy wytknęli Ukrainie dwutorowość prowadzonej wobec Moskwy polityki, ale jednocześnie sami podkreślali konieczność rozmów i ustępstw wobec niej. Zaznaczali, iż należałoby bardziej skoncentrować się na wspólnych interesach Europy i Rosji w zakresie sektora energetycznego, produkcji stali i żelaza oraz oczywiście praw człowieka i społeczeństwa obywatelskiego ${ }^{39}$. Ta rozbieżność poglądów z jednej strony zaskakuje, z drugiej zaś wyraźnie uświadamia, iż również Niemcy w swojej polityce zagranicznej

\footnotetext{
${ }^{31}$ Por. Plenarprotokoll 18/017, Deutscher Bundestag, Stenografischer Bericht, 17. Sitzung, Berlin den 20. Februar 2014, s. 16.

${ }^{32}$ Por. Plenarprotokoll 18/005, Deutscher Bundestag, Stenografischer Bericht, 5. Sitzung, Berlin den 18. Dezember 2013, s. 15, jak również por. Plenarprotokoll 18/010, Deutscher Bundestag, Stenografischer Bericht, 10. Sitzung, Berlin den 29. Januar 2014, s. 46.

${ }^{33}$ Por. Plenarprotokoll 18/005, Deutscher Bundestag, Stenografischer Bericht, 5. Sitzung, Berlin den 18. Dezember 2013, s. 24.

${ }^{34}$ Plenarprotokoll 18/010, Deutscher Bundestag, Stenografischer Bericht, 10. Sitzung, Berlin den 29. Januar 2014, s. 45.

${ }^{35}$ Por. Plenarprotokoll 18/005, Deutscher Bundestag, Stenografischer Bericht, 5. Sitzung, Berlin den 18. Dezember 2013, s. 15.

${ }^{36}$ Por. tamże, s. 14.

${ }^{37}$ Por. tamże, s. 15 .

${ }^{38}$ Por. tamże, s. 32.

${ }^{39}$ Por. Plenarprotokoll 18/012, Deutscher Bundestag, Stenografischer Bericht, 12. Sitzung, Berlin den 31. Januar 2014, s. 57; jak też: Plenarprotokoll 18/017, Deutscher Bundestag, Stenografischer Bericht, 17. Sitzung, Berlin den 20. Februar 2014, s. 16.
} 
nie pozostawali obojętni, ale uzależniali własne decyzje polityczne od narodowych korzyści ekonomicznych, w tym głównie od strategicznej strefy związanej z energetyką. Rozdrażnienie Moskwy mogłoby oznaczać dla Niemiec koniec wspólnych interesów i znaczące straty gospodarcze. Wprawdzie Rosja w tamtym czasie nie odgrywała dla niemieckiej gospodarki priorytetowej roli (nie była nawet w pierwszej dziesiątce głównych jej partnerów, jeśli chodzi o sprzedaż towarów), to jednak stanowiła 3,3\% jej eksportu (2013 r.), co w sumie dawało $36,1 \mathrm{mln}$ euro rocznie ${ }^{40}$.

Strategia miękkiego oddziaływania na Moskwę szczególnie uwidoczniła się podczas brutalnych starć z milicją, które odbiły się szerokim echem w Bundestagu. Kwestia stosowanej wobec cywilów przemocy wywołała szereg reakcji wśród niemieckich parlamentarzystów, którzy zwracali uwagę, iż należałoby stosować politykę rozmów i negocjacji. Powinna ona odnosić się zarówno do zebranych na ulicy ludzi, jak i do samej władzy ${ }^{41}$, w tym służb bezpieczeństwa prezydenta W. Janukowycza, wspierającego ataki radykalnych i antysemickich grup ${ }^{42}$. Dotyczyć ona miała także opozycjonisty Witalija Kliczki, wzywającego do tworzenia oddziałów milicji obywatelskiej w każdym domu, okręgu, a nawet podwórku ${ }^{43}$. Konieczność poparcia pokojowej strategii szczególnie mocno wspierał minister spraw zagranicznych F.-W. Steinmeier ${ }^{44}$, twierdząc, iż rząd federalny solidaryzuje się z każdym, kto upomina się o prawa podstawowe na Ukrainie, ale na zasadzie pokojowych rozwiązań ${ }^{45}$.

W kontekście niemilitarnych instrumentów prowadzenia polityki posłowie niemieckiego Bundestagu zastanawiali się również nad możliwością nałożenia sankcji na członków ukraińskiego rządu, ale kwestii tej poświęcono jedynie mały fragment debaty ${ }^{46}$. Nie uznano tego wątku za istotny, zwłaszcza że sekretarz stanu Federalnego Ministerstwa Spraw Zagranicznych M. Böhmer oświadczyła, iż władze federalne, choć nie wykluczają takiej możliwości, to jednakże nie przewidują obecnie konieczności praktykowania wspomnianego

\footnotetext{
${ }^{40}$ Por. C.-F. LAASER, K. SCHRADER, Das deutsche Russlandgeschäft im Schatten der Krise: gefährliche Abhängigkeiten?, „Wirtschaftsdienst”, 94. Jahrgang, 2014, z. 5, s. 336, DOI: 10.1007/s 10273-014-1676-8.

${ }^{41}$ Por. Plenarprotokoll 18/012, Deutscher Bundestag, Stenografischer Bericht, 12. Sitzung, Berlin den 31. Januar 2014, s. 60.

${ }^{42}$ Por. tamże, s. 60.

${ }^{43}$ Por. tamże, s. 61.

${ }^{44}$ Por. Plenarprotokoll 18/013, Deutscher Bundestag, Stenografischer Bericht, 13. Sitzung, Berlin den 12. Februar 2014, s. 65

${ }^{45}$ Por. tamże.

${ }^{46}$ Por. tamże, s. 34.
} 
narzędzia ${ }^{47}$. Wzbudziło to niepokój części deputowanych, którzy dostrzegali w tym bezradność oraz bezczynność niemieckiego rządu: „Docierające do nas w ciągu ostatnich dni informacje i obrazy z Kijowa oraz innych miejsc Ukrainy zszokowały nas wszystkich. Tygodniowe, pokojowe protesty setek tysięcy obywateli zostały krwawo stłumione [...], niosąc ze sobą znaczną liczbę rannych i ponad dwa tuziny zabitych zarówno po stronie demonstrantów, jak i sił bezpieczeństwa" ${ }^{\text {"48 }}$. „Nie chcemy, przemawiał na forum niemieckiego parlamentu N. Lammert (CDU), decydować, którą drogą i w jaką stronę powinna zmierzać Ukraina. Naszym obowiązkiem jest jednak, zaznaczył, występowanie w obronie praw podstawowych człowieka, w tym prawa każdego obywatela do decydowania, w jaki sposób chce żyć i być rządzonym"49.

Podkreślano zatem konieczność powrotu ukraińskiej władzy do rozwiązań konstytucyjnych z 2004 r. oraz rozpisania nowych wyborów ${ }^{50}$. Padła propozycja umiędzynarodowienia procesu pokojowego i włączenia $\mathrm{w}$ proces demokratyzacji Ukrainy takich ,aktorów”, jak: OBWE (Organizacja Bezpieczeństwa i Współpracy w Europie), Rada Europy, państwa członkowskie UE i sama Rosja. „Ukraina potrzebuje sąsiadów, którzy [...] będą pracować nad rzeczywistym partnerstwem" ${ }^{\text {"51 }}$. Należałoby zatem według opinii niemieckich polityków wzmocnić rolę Partnerstwa Wschodniego oraz zaangażować w działania także wysokiego przedstawiciela UE. Uwspólnotowienie zatem działań i ich koordynacja $\mathrm{z}$ W. Putinem stałaby się w przekonaniu deputowanych do Bundestagu drogą do pokojowej współpracy na kontynencie ${ }^{52}$. „Wygramy tylko dzięki kooperacji i integracji Europy albo stracimy wszystko poprzez destabilizację i niepewność w Europie" ${ }^{\circledR 3}$. Niemcy są bowiem - w przekonaniu zarówno samej kanclerz, jak i parlamentarzystów - z uwagi na bieżące wydarzenia na Ukrainie, ale również przez wzgląd na swoją historię, jak żaden inny kraj, wezwany do reakcji i solidarności z Ukrainą ${ }^{54}$.

Prowadzona w ten sposób narracja niemieckich polityków wyraźnie pokazała dwie kwestie. Po pierwsze, iż Niemcy wprawdzie dążyli do zmian na Ukrainie, ale nie za cenę zerwania własnych relacji z Moskwą. Na przeszkodzie stały im

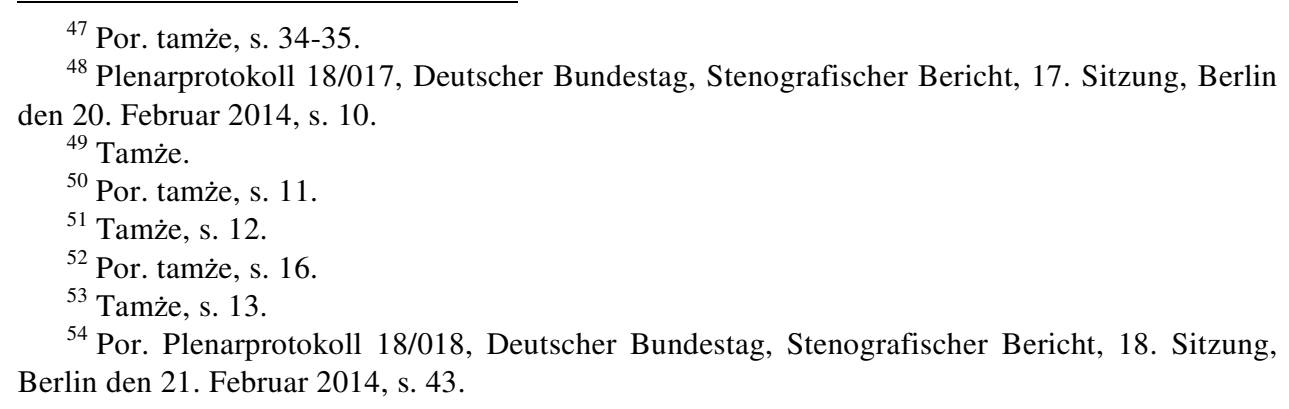


bowiem korzyści gospodarcze, z których czerpali znaczące profity. Nadto rząd federalny pod egidą UE starał się kreować na głównego mediatora i przywódcę politycznego w tym rejonie Europy, dystansując się, a nawet całkowicie pomijając Polskę, uważaną do tej pory za naturalny pomost między Europą Wschodnią a Zachodnią.

\section{PO MAJDANIE (27 II $2014-25$ V 2014)}

Okres „po Majdanie” koncentrował uwagę niemieckich deputowanych wokół tych samych kwestii co wcześniej, stanowiąc jedynie ich kontynuację bądź rozwinięcie. Niemniej jednym z ważniejszych wątków (poruszonych przez samą kanclerz A. Merkel) było wezwanie do redukcji ograniczeń handlowych oraz zwiększenia wysiłków na rzecz stabilizacji gospodarczej państwa. W przekonaniu Niemców nie powinny one zostać skierowane przeciw komukolwiek ani tym bardziej stanowić elementu federalnej geopolityki, ale pozostać jedynie istotną częścią stosunków sąsiedzkich ${ }^{55}$. Kanclerz odniosła się również do pomocy finansowej dla Ukrainy, na rzecz której UE przewidziała program wsparcia w wysokości 11 miliardów euro. Środki te miałyby służyć powołaniu specjalnej grupy ekspertów z MFW (Międzynarodowego Funduszu Walutowego) i wspierać program reform na Ukrainie, co ułatwiłoby współpracę gospodarczą i znacząco obniżyło $\mathrm{cła}^{56}$.

Niemieccy parlamentarzyści doskonale zdawali sobie bowiem sprawę z bilansu własnej współpracy z Europą Środkowo-Wschodnią, zwłaszcza tej mającej konsekwencje finansowe. Trwający tam konflikt w samym 2014 r. przyniósł im ogromne straty gospodarcze. Niemiecki handel z Europą Wschodnią po $2012 \mathrm{r}$. zaczął się drastycznie kurczyć: eksport do Rosji spadł o 18\%, na Ukrainę o 33\%, dotykając także sąsiednich krajów - Kazachstanu (spadek o 20\%) i Białorusi (o $21 \%)^{57}$. Ogółem niemiecki deficyt eksportowy w czterech wymienionych krajach wyniósł ponad 9 miliardów euro, a dostawy do samej Rosji obniżyły się z 35,8 mld euro do 29,3 mld euro (-6,5 mld euro), a na Ukrainę z 5,4 mld euro do 3,6 mld euro (-1,8 mld euro $)^{58}$.

\footnotetext{
${ }^{55}$ Por. Regierungserklärung, Plenarprotokoll 18/020, Deutscher Bundestag, Stenografischer Bericht, 20. Sitzung, Berlin den 13. März 2014, s. 8.

${ }^{56}$ Por. tamże.

${ }^{57}$ Por. Bundesverband Spedition und Logistik E.V., Ukraine-Konflikt hinterlässt tiefe Spuren in der deutschen Handelsbilanz, https://www.dslv.org/dslv/web.nsf/id/li_fdih9ugdeh.html (dostęp: 29.08.2020).

${ }^{58}$ Por. Regierungserklärung, Plenarprotokoll 18/020, Deutscher Bundestag, Stenografischer Bericht, 20. Sitzung, Berlin den 13. März 2014, s. 8
} 
Ciekawym i głośno debatowanym wątkiem był również - o czym wspominała m.in. A. Merkel - pomysł powołania międzynarodowej grupy kontaktowej oraz grupy obserwatorów OBWE, których obecność i praca miałyby ułatwić prowadzenie rozmów z Rosją. Zwracano szczególną uwagę na rozwiązania pokojowe i poszukiwanie dialogu z Moskwą, w tym na konieczność spotkania tzw. wielkiej czwórki (Ukrainy, Rosji, UE oraz USA) w celu wypracowania politycznego kompromisu wszystkich stron. Niezbędne - zdaniem niemieckich polityków - były też nowe wybory prezydenckie i parlamentarne na Ukrainie, w które włączeni powinni zostać „aktorzy” międzynarodowi, w tym mediatorzy z OBWE, przy jednoczesnym rozbrojeniu nielegalnych grup i usunięciu ich ze sfery publicznej, w tym również z budynków administracyjnych ${ }^{59}$.

Mówiąc o nieagresywnym podejściu, Niemcy bardzo mocno podkreślali swój zdecydowany sprzeciw wobec rozwiązań militarnych jako tych, które sprzyjają eskalacji napięcia i konfliktu. Za jedyną pożądaną metodę działań uważali dyplomację i to nie tyle niemiecką, ile europejską $\mathrm{z}$ aktywnym udziałem ODIHR (Biuro Instytucji Demokratycznych i Praw Człowieka) ${ }^{60}$ czy okrągłych stołów narodowego dialogu, realizowanych m.in. w ramach projektów OBWE, na które byli w stanie przekazać z własnego budżetu 2725000 euro $^{61}$.

Co więcej, nie tylko pokojowe rozwiązania stanowiły motyw przewodni niemieckich dyskusji, ale i przede wszystkim konieczność ułożenia pokojowych relacji w obrębie trójkąta Kijów-Moskwa-Berlin. Na forum Bundestagu dało się zatem słyszeć głosy, iż nakładanie embarg na Rosję W. Putinowi nie zaimponuje, a ,sankcje to nie wyraz strategii, ale jej braku”. Zatem nie pomoga one, a jedynie zaostrzą sytuację ${ }^{62}$, gdyż „odpowiedź Rosji, która nastąpi, dotknie [...] Europejki i Europejczyków, a zwłaszcza Niemców”63. „Ukraina ma przyszłość tylko wtedy, gdy będzie powiązana z Zachodem i ze Wschodem"64. „Potrzebujemy Rosji [...], ale Rosja potrzebuje także nas. [...] Rosja potrzebuje naszego Know-how, naszych technologii i naszej wiedzy, ale także

\footnotetext{
${ }^{59}$ Por. Plenarprotokoll 18/032, Deutscher Bundestag, Stenografischer Bericht, 32. Sitzung, Berlin den 7 Mai 2 Plenarprotokoll 2014, s. 26-27.

${ }^{60}$ Por. tamże, s. 26-28.

${ }^{61}$ Por. Plenarprotokoll 18/035 Deutscher Bundestag, Stenografischer Bericht, 35. Sitzung, Berlin den 21 Mai 2014, s. 62.

${ }^{62}$ Plenarprotokoll 18/020, Deutscher Bundestag, Stenografischer Bericht, 20. Sitzung, Berlin den 13. März 2014, s. 12.

${ }^{63}$ Plenarprotokoll 18/023, Deutscher Bundestag, Stenografischer Bericht, 23. Sitzung, Berlin den 20. März 2014, s. 16.

${ }^{64}$ Tamże, s. 34.
} 
naszych dochodów z surowców, które nam sprzedaje”, dlatego też RFN powinna mówić wraz z innymi krajami UE jednym głosem ${ }^{65}$.

Jako nietypową i oryginalną metodę rozwiązania konfliktu wieloetniczności mieszkańców Ukrainy część niemieckich deputowanych zaproponowała przekształcenie Ukrainy w federację bądź też ewentualnie w luźniejszą jej formę - konfederację ${ }^{66}$. Dzięki temu ich zdaniem możliwe byłoby zachowanie jedności kraju i pogodzenie jego różnorodnych, regionalnych interesów ${ }^{67}$. Zaproponowano przyjęcie niemieckiego modelu rozwiązań systemowych, podwójną prezydenturę oraz heterogeniczność językową jako gwarantów pokojowego współżycia Rosjan i Ukraińców. Wątek ten, choć pojawił się kilkakrotnie na forum Bundestagu, nie doczekał się jednak ani uszczegółowienia, ani też konkretnych działań.

\section{PODSUMOWANIE I WNIOSKI}

Odpowiadając na postawione we Wprowadzeniu pytania, należy zaznaczyć, iż niemiecki dyskurs parlamentarny w sposób szczególny uwypuklił, iż: 1. niemieckie plany rozwiązania konfliktu na Ukrainie dążyły do posiadania decydującego głosu odnośnie do zachodzących tam zmian; 2. rząd A. Merkel starał się zinstytucjonalizować własne przedsięwzięcia (koniecznie bazując na strukturach unijnych) tak, by za ich pomocą móc oddziaływać zarówno w sposób formalny, jak i nieformalny; 3. Niemcy bardzo chętnie widzieliby Ukrainę jako państwo federalne oparte na modelu niemieckim; 4. starali się też oni wyprzeć z narracji i świadomości politycznej Polskę jako pomost między Europą Wschodnią a Zachodnią, chcąc jednocześnie zająć jej miejsce; 5. kanclerz A. Merkel pragnęła takiego ułożenia stosunków międzynarodowych, by jednocześnie pozostać w korzystnych (zwłaszcza gospodarczo) relacjach zarówno z Rosją, jak i Ukrainą.

Jeśli chodzi o dynamikę debaty, to należy zaznaczyć, iż miała ona charakter trzyetapowy: od dyskusji o ogólnych wartościach typu sport poprzez promocję miękkich narzędzi oddziaływania zarówno na W. Janukowycza, jak i na Rosją aż po konkretyzację strategii, która dałaby RFN szansę rozszerzenia własnych wpływów na Ukrainie. Zaznaczyć przy tym należy, iż Niemcom nie zależało

\footnotetext{
${ }^{65}$ Plenarprotokoll 18/032, Deutscher Bundestag, Stenografischer Bericht, 32. Sitzung, Berlin den 7 Mai 2014, s. 40.

${ }^{66}$ Por. tamże, s. $28-29$.

${ }^{67}$ Por. tamże, s. 34.
} 
na oddziaływaniu politycznym (te pozostawili Rosji), ile na uzyskaniu dostępu do sfery gospodarczej. Co więcej, analiza dyskursu parlamentarnego wykazała w szczególności, iż wątek łamania praw człowieka i zasad państwa prawa był obecny w Bundestagu, zanim jeszcze ukonstytuował się tzw. Majdan. Niemniej jednak poruszane wówczas wątki nie dotyczyły stricte politycznych kwestii, a oscylowały głównie wokół tematu sportu (rozgrywek Euro 2012) oraz sytuacji ukraińskich grup mniejszości seksualnych i ich dyskryminacji. W tle jako tematy drugo- i dalszoplanowe pojawiały się jednak zagadnienia interesów narodowych Niemiec w tej części Europy, zwłaszcza w kontekście stosunków gospodarczych z Rosją i ewentualnym partnerstwem z Ukrainą.

Nadto Niemcy już wtedy dążyli, czemu dali też wyraz w prowadzonej na forum parlamentu dyskusji, do tego, by zyskać pozycję jednego z ważniejszych, jeśli nie jedynego partnera do rozmów z Moskwą. Stanowiło to swoistą kontynuację wcześniejszej strategii rządu federalnego (Russia first). Swoją politykę starali się też z jednej strony legitymizować wartościami europejskimi (wyciszając akcenty stricte narodowe), z drugiej „kusząc” obie strony konfliktu perspektywą ewentualnych korzyści finansowych, generowanych jako pomoc i wsparcie budżetowe. Oczywiście nie pozostawali w tym bezinteresowni, ale widzieli siebie jako przyszłego reprezentanta i promotora kultury Zachodu w Europie Środkowo-Wschodniej. Chcieli dzięki temu nie tylko utorować sobie monopol wpływów gospodarczych na tym terenie, ale stać się również głównym partnerem handlowym dla tej części kontynentu. $Z$ dystansem jednak i ostrożnością wypowiadali się, jeśli w ogóle (co widać było zwłaszcza w powściągliwości kanclerz A. Merkel) na temat zmian politycznych na Ukrainie i w Rosji, choć i takie wątki się pojawiały.

Można zatem powiedzieć, iż narracja niemieckich polityków zdecydowanie największy nacisk kładła na możliwości ekonomicznej współpracy z Ukrainą i stworzenia na tyle dogodnych warunków, by nie zachwiało to rynkiem federalnym, niż na skutecznych działaniach politycznych. Strategię tą potwierdzają chociażby przytaczane wcześniej dane statystyczne wyraźnie wskazujące na dynamikę stosunków gospodarczych Niemiec z Ukrainą i Rosją. O ile bowiem do 2014 r. RFN cieszyć się mogło znacznym ich wzrostem, odnotowując z kolei w latach 2014-2016 duże straty, to po tym okresie ponownie zyskało w obrotach handlowych z samą Ukrainą o 2,7\% ${ }^{68}$, a z Rosją (z 2016 na 2017 r.) o ok. $4 \%{ }^{69}$.

\footnotetext{
${ }^{68}$ Por. F. NEMITZ, Außenhandel der Ukraine spiegelt Konflikt mit Russland wider, Germany Trade \& Invest ist die Gesellschaft der Bundesrepublik Deutschland für Außenwirtschaft und Standortmarketing 26.09.2017, https://www.gtai.de/gtai-de/trade/wirtschaftsumfeld/berichtwirtschaftsumfeld /ukraine/aussenhandel-der-ukraine-spiegelt-konflikt-mit-russland-wider-19528 (dostęp: 29.08.2020).
} 
Co więcej, Niemcy pozostawali także (od 2016 r.) jednym z najważniejszych inwestorów zagranicznych w Rosji w tamtym czasie, co nie pozostawało bez znaczenia.

Okres „Majdanu” natomiast ujawnił dwie pozostałe kwestie. Po pierwsze, asymetrię działań politycznych $\mathrm{w}$ sferze międzynarodowej oraz dążenia Niemiec do instytucjonalizacji własnych działań na Ukrainie. Odnośnie do pierwszego, niemieccy parlamentarzyści zwracali szczególną uwagę na słabość i niekonsekwencję działań ukraińskiego rządu wobec Rosji (polityka „Tak, ale...”) oraz uległość wobec stosowanej przez nią presji, które przejawiały się chociażby podpisywaniem z nią umów międzynarodowych z jednej strony i występowaniem wobec jej mocarstwowej polityce $\mathrm{z}$ drugiej. Co interesujące, Niemcy, krytykując Ukrainę, sami działali według podobnego schematu. Jedynie Moskwa okazała się być zdecydowanym i „twardym graczem”, ale tylko dlatego, że posiadając zdecydowanie większe możliwości dostępu do innych rynków zbytu (chociażby w swoich byłych republikach), mogła sobie pozwolić, w przeciwieństwie do Niemiec, na politykę zero-jedynkową.

Druga kwestia, to instytucjonalizacja działań niemieckich na Ukrainie. Tę rząd federalny widział przede wszystkim jako aktywność Partnerstwa Wschodniego i Unii Europejskiej, co pozwalało mu też ,zeuropeizować” własne interesy narodowe i dać szersze możliwości formalnej współpracy z Europą Środkowo-Wschodnią. Otwierało to też drzwi, co pokazała debata, do prowadzenia nielegalnych interesów handlowych w postaci chociażby wspomnianych fabryk działających w szarej strefie i na pograniczu prawa.

Trzecia część debaty, przebiegająca już „Po Majdanie”, dotyczyła przede wszystkim dążenia niemieckich polityków do włączenia w proces pokojowy na Ukrainie partnerów międzynarodowych oraz do wsparcia finansowego wspomnianych przedsięwzięć zarówno z budżetu federalnego, jak i unijnego. Nadto (o czym niemieccy parlamentarzyści wyraźnie mówili) pragnęli oni ukształtowania takiej struktury organizacyjno-terytorialnej Ukrainy, by przyjęła ona model rozwiązań niemieckiego federalizmu. To również jest transparentną cechą niemieckich działań na scenie międzynarodowej i przejawia się chyba najmocniej w konstrukcji obecnej $\mathrm{UE}^{70}$, w której Niemcy odgrywają obecnie niekwestionowanie przywódczą rolę. Organizacja systemu politycznego według własnego schematu daje bowiem tę przewagę, że zdecydowanie

\footnotetext{
${ }^{69}$ Por. Bundesministerium für Wirtschaft und Energie, Russische Föderation - Wirtschaftliche Beziehungen, https://www.bmwi.de/Redaktion/DE/Artikel/Aussenwirtschaft/laendervermerk-russische -foerderation.html (dostęp: 29.08.2020).

${ }^{70}$ Por. M. OlewińSKA, Federalizm w Unii Europejskiej i w Niemczech. Modele i powiazania, Kraków 2007, s. 91-113.
} 
łatwiej jest oddziaływać (w różnym wymiarze: politycznym, gospodarczym, kulturowym itp.), jeśli mechanizmy instytucjonalne i decyzyjne pozostają do siebie zbliżone. Co równie ważne w niemieckiej debacie parlamentarnej, wyraźnie też dały się słyszeć głosy, by inicjatywę w tej części kontynentu Europy przejęła UE oraz stojąca za nią RFN (co nie zostało już tak dosadnie wypowiedziane), choć A. Merkel niejednokrotnie powtarzała, iż Niemcy będą tylko wtedy silne, gdy silna będzie cała Europa ${ }^{71}$.

Podsumowując, konflikt na Ukrainie pokazał, iż Niemcom w pierwszej kolejności chodziło o własne interesy, a dopiero ewentualnie później o wolność i demokratyzację Ukrainy. Rozbieżność interesów więc, a co za tym idzie i mówienie „różnymi językami”, tzn. praktykowanie przez jedną ze stron wyłącznie twardej, a przez drugą tylko miękkiej siły, nie rozwiązało problemu, przeciągnęło proces pokojowy i w efekcie końcowym niestety (przynajmniej na ten moment), co pokazuje przykład aneksji Krymu, dało przewagę hard power. Być może jest to także zadanie na przyszłość i kwestia do refleksji nad koniecznością wypracowania jeszcze innego podejścia i strategii wobec Rosji.

\section{BIBLIOGRAFIA}

ANTAS Ł., Relacje gospodarcze Niemiec z krajami Europy Środkowo-Wschodniej, w: Relacje gospodarcze Niemiec z krajami Europy Środkowo-Wschodniej, red. K. Kazimierska, Warszawa: Ośrodek Studiów Wschodnich 2008.

Bundesministerium für Wirtschaft und Energie, Russische Föderation - Wirtschaftliche Beziehungen, https://www.bmwi.de/Redaktion/DE/Artikel/Aussenwirtschaft/laendervermerkrussische-foerderation.html (dostęp: 29.08.2020).

Bundesverband Spedition und Logistik E.V., Ukraine-Konflikt hinterlässt tiefe Spuren in der deutschen Handelsbilanz, https://www.dslv.org/dslv/web.nsf/id/li_fdih9ugdeh.html (dostęp: 29.08.2020).

Deutsche Botschaft, 25 Jahre diplomatische Beziehungen zwischen Deutschland und der Ukraine, erschienen in „Dserkalo tyshnja” am 17.01.2017 Kiew, https://kiew.diplo.de/uade/themen /willkommen/artikel-25-jahre-st-kl/1283092 (dostęp: 13.08.2020).

Deutscher Bundestag, Keine Eishokey-Weltmeisterschaft 2014 in Bielarus, Drucksache 17/9557, 9. Mai 2012, http://dip21.bundestag.de/dip21/btd/17/095/1709557.pdf (dostęp: 10.09.2014).

Dziennik.pl, Była, a jakby jej nie było. Cicha wizyta Merkel u niemieckich piłkarzy, dziennik.pl 7.06.2012, https://www.dziennik.pl/euro2012dziennikpl/galeria/393400,kanclerz-niemiec-angela-merkel-odwiedzila-w-gdansku-niemieckich-pilkarzy-przed-pilkarskimi-mistrzostwamieuro-2012.html (dostęp: 16.08.2020).

\footnotetext{
${ }^{71}$ Por. Regierungserklärung, Plenarprotokoll 18/005, Deutscher Bundestag, Stenografischer Bericht, 5. Sitzung, Berlin den 18. Dezember 2013, s. 7, jak również: por. Regierungserklärung, Plenarprotokoll 18/010, Deutscher Bundestag, Stenografischer Bericht, 10. Sitzung, Berlin den 29. Dezember 2014, s. 5.
} 
Deutscher Bundestag, Umfassende Visaliberalisierung für Menschen in Russland und Osteuropa, Drucksache 17/191, 28. März 2012, http://dip21.bundestag.de/dip21/btd/17/091/1709191.pdf (dostęp: 12.09.2014).

GRIESS A., Was Deutschland in die Ukraine liefert, Statista 14.05.2014, https://de.statista.com/info grafik/2245/anteil-der-gesamtausfuhr-deutscher-ausfuhrgueter-nach-sitc/ (dostęp: 15.08.2020).

GUTOWSKa J., Niemcy wobec Partnerstwa Wschodniego, „Ośrodek Studiów Wschodnich”, nr 37, 17.06.2010, https://www.osw.waw.pl/sites/default/files/komentarze_37_0.pdf (dostęp: 20.08.2020).

LAASER C.-F., SCHRADER K., Das deutsche Russlandgeschäft im Schatten der Krise: gefährliche Abhängigkeiten?, „Wirtschaftsdienst”, 2014, 94. Jahrgang, z. 5, DOI: 10.1007/s10273-014-1676-8.

Malinowski K., Polityka Niemiec wobec Europy Wschodniej: Russia first?, „Przegląd Polityczny” 2015, nr 4, DOI: https://doi.org/10.14746/pp.2015.20.4.2.

Nemitz F., Außenhandel der Ukraine spiegelt Konflikt mit Russland wider, Germany Trade \& Invest ist die Gesellschaft der Bundesrepublik Deutschland für Außenwirtschaft und Standortmarketing 26.09.2017, https://www.gtai.de/gtai-de/trade/wirtschaftsumfeld/bericht-wirtschaftsumfeld/ukraine /aussenhandel-der-ukraine-spiegelt-konflikt-mit-russland-wider-19528 (dostęp: 29.08.2020).

OlEwIŃSKA M., Federalizm w Unii Europejskiej i w Niemczech. Modele i powiązania, Kraków 2007.

Plenarprotokoll, 17/181, Deutscher Bundestag, Stenografischer Bericht, 181. Sitzung, Berlin den 24. Mai 2012.

Plenarprotokoll, 17/184, Deutscher Bundestag, Stenografischer Bericht, 184. Sitzung, Berlin den 14. Juni 2012, s. 204.

Plenarprotokoll, 17/192, Deutscher Bundestag, Stenografischer Bericht, 192. Sitzung, Berlin den 13. September 2012.

Plenarprotokoll, 17/231, Deutscher Bundestag, Stenografischer Bericht, 231. Sitzung, Berlin den 21. März 2013.

Plenarprotokoll, 18/005, Deutscher Bundestag, Stenografischer Bericht, 5. Sitzung, Berlin den 18. Dezember 2013.

Plenarprotokoll, 18/010, Deutscher Bundestag, Stenografischer Bericht, 10. Sitzung, Berlin den 29. Januar 2014.

Plenarprotokoll, 18/012, Deutscher Bundestag, Stenografischer Bericht, 12. Sitzung, Berlin den 31. Januar 2014.

Plenarprotokoll, 18/013, Deutscher Bundestag, Stenografischer Bericht, 13. Sitzung, Berlin den 12. Februar 2014.

Plenarprotokoll, 18/017, Deutscher Bundestag, Stenografischer Bericht, 17. Sitzung, Berlin den 20. Februar 2014.

Plenarprotokoll, 18/018, Deutscher Bundestag, Stenografischer Bericht, 18. Sitzung, Berlin den 21. Februar 2014.

Plenarprotokoll, 18/020, Deutscher Bundestag, Stenografischer Bericht, 20. Sitzung, Berlin den 13. März 2014.

Plenarprotokoll, 17/187, Deutscher Bundestag, Stenografischer Bericht, 187. Sitzung, Berlin den 28. Juni 2012.

Plenarprotokoll, 17/194, Deutscher Bundestag, Stenografischer Bericht, 194. Sitzung, Berlin den 26. September 2012. 
Plenarprotokoll, 18/003, Deutscher Bundestag, Stenografischer Bericht, 3. Sitzung, Berlin den 28. November 2013.

Plenarprotokoll, 18/012, Deutscher Bundestag, Stenografischer Bericht, 12. Sitzung, Berlin den 31. Januar 2014.

Plenarprotokoll, 18/023, Deutscher Bundestag, Stenografischer Bericht, 23. Sitzung, Berlin den 20. März 2014.

Plenarprotokoll, 18/032, Deutscher Bundestag, Stenografischer Bericht, 32. Sitzung, Berlin den 7 Mai 2014.

Plenarprotokoll, 18/035 Deutscher Bundestag, Stenografischer Bericht, 35. Sitzung, Berlin den 21 Mai 2014.

Pöhle S., Steinmeiers Ukraine-Problem, Deutsche Welle 20.12.2013, https://www.dw.com/de/ steinmeiers-ukraine-problem/a-17306377 [dostęp: 13.08.2020].

Regierungserklärung, Plenarprotokoll 17/178, Deutscher Bundestag, Stenografischer Bericht, 178. Sitzung, Berlin den 10. Mai 2012.

Regierungserklärung, Plenarprotokoll 17/179, Deutscher Bundestag, Stenografischer Bericht, 179. Sitzung, Berlin den 11. Mai 2012.

Regierungserklärung, Plenarprotokoll 18/002, Deutscher Bundestag, Stenografischer Bericht, 2. Sitzung, Berlin den 18. November 2013.

Regierungserklärung, Plenarprotokoll 18/005, Deutscher Bundestag, Stenografischer Bericht, 5. Sitzung, Berlin den 18. Dezember 2013.

Regierungserklärung, Plenarprotokoll 18/010, Deutscher Bundestag, Stenografischer Bericht, 10. Sitzung, Berlin den 29. Dezember 2014.

Regierungserklärung, Plenarprotokoll 18/020, Deutscher Bundestag, Stenografischer Bericht, 20. Sitzung, Berlin den 13. März 2014.

URmENSBACH M., Export von Gütern aus der Ukraine bis 2019, Statista 28.04.2020, https://de.statista.com/statistik/daten/studie/314545/umfrage/export-von-guetern-aus-der-ukraine/ (dostęp: 15.08.2020).

„Wprost”, Merkel nie zaplanowała wyjazdu na Euro 2012, wprost.pl 4.06.2012, https://www.wprost.pl/326323/merkel-nie-zaplanowala-wyjazdu-na-euro-2012.html (dostęp: 16.08.2020).

\section{KONFLIKT NA UKRAINIE \\ W NIEMIECKIM DYSKURSIE PARLAMENTARNYM}

Streszczenie

Artykuł stanowi analizę narracji parlamentarnej niemieckich deputowanych do Bundestagu, prowadzonej na przestrzeni dwóch lat (od 2012 do 2014 r.) w związku z kryzysem na Ukrainie. Badania nad dyskursem miały za zadanie wskazać na najważniejsze dla niemieckich parlamentarzystów wątki oraz preferowane przez rząd federalny metody rozwiązania sporu na linii Kijów-Moskwa. Opracowanie to stanowi próbę wyjaśnienia, dlaczego rząd A. Merkel zaangażował się w konflikt, jaką widział w nim swoją rolę i jakie korzyści własne? Celem artykułu było również zarysowanie ewolucji poruszanych w trakcie debaty wątków w kontekście strategicznych interesów narodowych (głównie gospodarczych) Niemiec i kształtowania przez nich własnej 
polityki zagranicznej, która gwarantowałaby im maksymalizację własnych wpływów przy jednoczesnym unikaniu ostrego starcia z Rosją. To bowiem mogłoby negatywnie odbić się na wskaźnikach ekonomicznych Niemiec, czego one za wszelką cenę starały się uniknąć. Prezentowana perspektywa pozwala zatem, przynajmniej częściowo, zrozumieć zarówno niemiecką taktykę soft power, jak i pewną uległość kanclerz wobec W. Putina i jego zaborczej polityki na Ukrainie.

Słowa kluczowe: Ukraina; konflikt; Niemcy; dyskurs parlamentarny; Rosja; gospodarka.

\section{THE CONFLICT IN UKRAINE IN THE GERMAN PARLIAMENTARY DISCOURSE}

\section{Summary}

The article is an analysis of the parliamentary discourse of Bundestag deputies, led over two years, i.e. from 2012 to 2014 regarding the crisis in Ukraine. The studies on the discourse were aiming to indicate the most important issues for the German parliamentarians and ways of resolving the Kyiv-Moscow conflict preferred by the federal government. The essay is an attempt of explanation why A. Merkel's government got involved in the conflict, what was its perceived role and own benefits. The aim of the article was also to outline the evolution of the issues raised in the debate in the context of Germany's strategic national interests (mainly the economic ones) and forming their foreign policy guaranteeing to maximize their influence and avoiding an acute conflict with Russia at the same time. This could negatively affect German economic indications, which they wanted to avoid at all costs. Therefore, the perspective presented herein enables to understand, at least to some degree, the German soft power tactics and a certain amount of the Chancellor's submission to W. Putin and his invasive politics in Ukraine.

Keywords: Ukraine, conflict; Germany; parliamentary discourse; Russia; economy. 